\title{
New Testament and Digital Humanities
}

Alliance biblique française, online: https://lire.la-bible.net (Jun 7, 2020). - Deutsche Bibelgesellschaft, online: https://www.die-bibel.de/ (Jun 7, 2020). - Digital Editio Critica Maior, online: https://ntvmr.uni-muenster.de/ecm (Jun 7, 2020). - Early Christianity: The Letters of Paul, online: https://www.edx.org/course/early-christianity-letters-paul-harvardx-hds1544-1x (Jun 7, 2020). - New Revised Standard Version, online: https://www.zondervan.com/p/nrsv-2/ (Jun 7 , 2020). - New Testament Virtual Manuscript Room, online: http://ntvmr.uni-muenster.de/ (Jun 7 , 2020). - SBL Bible Odyssey, online: https://www.bibleodyssey.org/ (Jun 7, 2020). - YouVersion, https://www.youversion.com (Jun 7, 2020).

Further Literature

Garrick Allen, Digital Tools for Working with New Testament Manuscripts: Open Theology 5 (2019/1) 13-28, online: https://doi.org/10.1515/opth-2019-0002 (Jun 7, 2020). - Roberto Busa, Foreword: Perspectives on the Digital Humanities: Susan Schreibman/Ray Siemens/John Unsworth (eds.), A Companion to Digital Humanities, Blackwell Edinburgh 2004, xxvii + 611 p., DOI: 10.1002/9780470999875 (Jun 7, 2020). - Roger Chartier, Les métamorphoses du livre. Les rendez-vous de l'édition. Le livre et le numérique, Bibliothèque du Centre Pompidou Paris 2001, 35 p., online: https://books.openedition.org/bibpompidou/1702 (Jun 7, 2020). - Claire Clivaz, Écritures digitales. Digital writing, digital scriptures (Digital Biblical Studies 4), Brill Leiden 2019, vi + 290 p., DOI: https://doi.org/10.1163/9789004402560 (Jun 7, 2020). - Claire Clivaz/ Garrick Allen (eds.), The Digital Humanities in Biblical Studies and Theology: Open Theology 5 (2019/1), DOI: https://doi.org/10.1515/opth-2019-0035 (Jun 7, 2020). - Juan Garcés/Jan Heilmann, Digital Humanities und Exegese. Erträge, Potentiale, Grenzen und hochschuldidaktische Perspektiven: Forum Exegese und Hochschuldidaktik: Verstehen von Anfang an 2 (2017/2) 29-52. - Hugh Houghton, Electronic Transcriptions of New Testament Manuscripts and their Accuracy, Documentation and Publication: David Hamidović/Claire Clivaz/Sarah Bowen Savant (eds.), Ancient Manuscripts in Digital Culture (Digital Biblical Studies 3), Brill Leiden 2019, 79-91, online: https://doi.org/10.11639789004399297_009 (Jun 7, 2020). - Stanley Jones, Roberto Busa, S.J. and the emergence of Humanities Computing. The priest and the punched cards, Routledge New York 2016, VI + 186 p., DOI: 10.4324/9781315643618 (Jun 7, 2020). - Sarah Mombert, From Books to Collections. Critical Editions of Heterogeneous Documents: Claire Bélisle/Daniel Apollon/Philippe Régnier (eds.), Digital Critical Editions (Topics in the Digital Humanities), University of Illinois Press Urbana (Illinois) 2014, 246-265. - David Parker, An introduction to the New Testament manuscripts and their texts, Cambridge University Press Cambridge 2008, xxx + 368 p. - Jennifer Quigley/Laura Nasrallah, HarvardX's Early Christianity: The Letters of Paul. A Retrospective on Online Teaching and Learning: David Hamidović/Claire Clivaz/ Sarah Bowen Savant (eds.), Ancient Manuscripts in Digital Culture (Digital Biblical Studies 3), Brill Leiden, 2019, 217-240, online: https://doi.org/10.1163/9789004399297_012 (Jun 7, 2020).

It has never been easier to find New Testament (NT) resources online, from German language translations to New Testament manuscripts, commentaries, and articles. But it has also become tricky to identify the accuracy or origin of an online resource, as the internet is potentially a tool »without any distinction between truth and error«(U. Eco, The Infinity of Lists, New York NY 2009, 327).

Paying careful attention to these issues, this article will first summarize the current status of the NT and digital humanities (DH), then present four online tools for NT study that are open access $(\mathrm{OA})$ and born digital: the biblical application YouVersion (with an overview of translations of the Bible in German, French and English, section 2), the encyclopedia from the Society of Biblical 
Literature, Bible Odyssey (section 3), a Harvard teaching MOOC Early Christian Letters of Paul (section 4), and what I propose to name the »Digital Editio Critica Maior « (DECM) with the NT Virtual Manuscript Room (NTVMR) (section 5).

The writing of this article has been supported by the SNSF PRIMA project MARK16; some passages come from a previously published de Gruyter article in CC BY-SA 4.0 license (https:// doi.org/10.1515/opth-2019-0035 [Jun 7, 2020]) or are translated from a French book (Clivaz, Écritures) with the kind permission of the publishers.

\section{Perspectives on the state of the art: Bible and New Testament in digital culture}

It is well known that the first computing tool built for the humanities was the Index Thomisticus, created by Jesuit Roberto Busa. Soon thereafter, the Reverend John W. Ellison produced the first computing tool for biblical studies, an index of the English translation of the Revised Standard Version (Jones, 100f.). This traditional Anfangspunkt in the history of $\mathrm{DH}$ has often promoted Roberto Busa to the position of »father of the discipline«, a prominent role demonstrated by his enthusiasm for DH, going so far as to compare him to the »finger of God « (Busa). In the early 1990s, the field of biblical studies relied on and advanced alongside the $\mathrm{DH}$ to a greater extent than any other discipline in the humanities (Garcés/Heilmann, 30). But critical reflection on the relationship between the $\mathrm{DH}$ and theology has been slow to emerge: Jeffrey Siker's »Liquid Scripture«, the first monograph devoted to the Bible in digital culture, was published in 2017, only sixty years after the biblical index built by Ellison. Siker's work was followed in quick succession by C. Clivaz's »Écritures digitales « and P. Phillips' »The Bible, Social Media and Digital Culture« (2019 both).

This substantial six decade gap reflects the transformation of the biblical text influenced by the beginning of digital culture, as well as the multimodal expression of the Bible and theological discourse in digital culture. To reflect on this expanding field, a special »Open Theology « issue was published in 2019 on Digital Humanities, demonstrating the relevance of digital theology (Clivaz/Allen). Generic tools (not available in OA) such as »Bibleworks «, »Accordance«, and »Logos «, are now widely used, alongside OA biblical applications like »YouVersion«.

Such innovations raise questions for Christian theology, particularly the Reformed confession, for whom the Scriptures are of primary importance. In observance of the 500th anniversary of the Reformation, the former Schweizerischer Evangelischer Kirchenbund (SEK), now Evangelisch-reformierte Kirche Schweiz (EKS), published a commemorative study (https://www.evref. ch/publikationen/sola-lectura/ [Jun 7, 2020]) entitled, "Sola lectura? (not »Sola scriptura«). It is an important text that dares to go beyond the traditional notion of »religion of the book, « qualifying it as »historische Begleiterscheinung (p. 7f.). The German version refers to the »emancipation « of writing from the confines of books, whereas the French version defines it as $a$ »dissociation entre l'écrit et le livre« (p. 10 both). Emancipation or dissociation? These two words clearly illustrate the ambiguity of the Reformed confession in the face of the digital turn. It is therefore relevant to consider the Reformed theologian Karl Barth's explanation of the process of writing his commentary on Romans: he did not want to »write a book « but rather reach an 
»imperceptible community« (»unsichtbare Gemeinschaft«; quoted by C. Clivaz in ZNT No. $39 / 40$ [2017] 39). The purpose behind the message, therefore, determines the motive for writing.

\section{Online translations of the Bible and the software application YouVersion}

At first glance, it would seem obvious to find the major translations of the Bible in OA with notes. However, upon further inspection, this is not the case for German, English, and French translations.

German reference Bible translations are available online in OA on a reference website, Deutsche Bibelgesellschaft, specifically the »Lutherbibel 2017 «, »der zum Gebrauch empfohlene Bibeltext der Evangelischen Kirche in Deutschland (EKD) «, and the "Zürcher Bibel «, »eine gediegene Übersetzung von hohem Niveau «, as their websites indicate. It must be noted that one can only get the translated text in $\mathrm{OA}$, and not the footnotes and comments of these editions; they remain only partly in OA. Similarly, in regards to the reference edition of the Greek New Testament edited by the Deutsche Bibelgesellschaft, the Nestle-Aland 28th edition, the Greek text is available in OA, but not the apparatus criticus. This website does not provide multimodal material. When it comes to French translations, La Traduction Oecuménique de la Bible (TOB) is not available in OA on the publisher website, Le Cerf. It was accessible several years ago, and there are archives of websites detailing requests to withdraw the TOB online, for example on the Dominicans website trader.org. However, the 2010 TOB version was co-edited with the Sociéte biblique française, now L'Alliance biblique française, that provides a TOB version in OA on its website, without notes, with five other French translations. There is also a link providing a few videos, but it is not possible to listen to the biblical text. Last but not least, in a 2017 report, L'Alliance biblique française revealed that one-fifth of Bibles are now downloaded online through the software application YouVersion, instead of purchased as paper books.

The English reference translation called the New Revised Standard Version (NRSV) is not available in OA on the Zondervan's website. Depending on the situation, the US National Council of Churches may or may not give NRSV copyright permission in OA. For example, BibleGateway, a Zondervan tool, does not have NRSV, however it is available on Biblestudytools and Bible. com, the website of YouVersion.

In other words, a reader must go through an interpretive framework to find the NRSV in OA, since it is unavailable on the publisher's website. In this context, the YouVersion app and Bible.com are becoming the common places to access NRSV and other translations. The Bible is available in 900 languages on YouVersion, in 1,200 versions, including many audio Bibles and a library of biblical videos. The app claims to have been downloaded more than 404,573,000 times. Images can be joined to biblical verses, giving them new meanings. YouVersion was created by Life.church, founded in the USA in 1997, with 13 communities and counting as of 2009 .

According to T. Hutchings, YouVersion (similar to Globible) offers »extensive libraries, with audio and multi-media options and thousands of texts to choose from, but their portfolios are not infinite. Contents are carefully chosen, as are the user's options for navigation through the library. At times, as indicated above, the digital product can even go against the user's independence, offering advice, reprimanding the wayward, and using the techniques of persuasive technology to form new habits of textual engagement. [...] My evidence demonstrates that the funders, de- 
signers, and marketers of some digital Bibles are trying hard to promote a traditional Evangelical attitude to the Bible« (T. Hutchings, Design and the Digital Bible: Persuasive Technology and Religious Reading: JCR 32 [2017], 205-219, http://dx.doi.org/10.1080/13537903.2017.1298903 [Jun 7, 2020], here 215f.).

Such observations should provoke critical thought for the church, considering the fact that YouVersion is providing more than one-fifth of the Bibles purchased every year worldwide. At the same time, it is an interesting tool to be used in church for teaching teens and adults, with a critical perception of the material surrounding the texts themselves. All participants in theological education, from the minister to the professor of theology, should be concerned by the fact that we do not currently have an accurate translation of the Bible with notes and comments available in OA in German, French, or English. An urgent discussion with publishers is needed on this topic.

\section{The web portal "Bible Odyssey"}

Bible Odyssey is a multimedia biblical encyclopedia, under the umbrealla of the Society of Biblical Literature. SBL produces this OA and born digital tool, attesting to the quality of the content, with articles written by established scholars. It aims to "address not only the literacy gap but also the gap between the academy and the >street « in regards to the Bible. It is divided in three sections: people, places, and passages, and it also offers Bibles and tools with audio and video galleries. Resources are conclusively multimodal, implying texts and images, or texts and audios, or all the three together. The multimodality is one of the big transformations of the Bible in digital culture.

Over the past several years, Biblical exegesis has become increasingly influenced by orality, notably with the emergence of "performance criticism« (B. Oestreich/G. Holland) and »visual exegesis «(V. Robbins/W. Melion). However, the main multimodal impact on Scriptures is due to the widespread use of biblical applications or websites like Bible Odyssey. The creation of multimodal digital expressions of the Scriptures brings about several new theological challenges, from exegesis to practical theology, ethics, and systematic theology. It blurs the boundaries between the diverse literary genres, a general phenomenon in digitized Humanities, noted by R. Chartier (Chartier, 12-14).

One can find examples of these blurred lines in Bible Odyssey by consulting the list of places. No context is given for real geographical places like Alexandria, Antioch, and Bethlehem listed alongside Hell, without quotations marks, or »Kingdom of God « and »Kingdom of Heaven « with quotations marks. It is not evident whether laypeople targeted by the tool will get accurate information from this complex depiction of theological geography. This example demonstrates that the best use of this tool would be in a church context, training teens and adults. Theology students will also surely find useful information, if they consider the resources as basic information, accompanied with images and/or audio material. 


\section{Teaching New Testament online: "Early Christian letters of Paul«}

There is currently a global challenge of education through MOOC in religious fields, and the online edX/HarvardX course, Early Christianity: The Letters of Paul, launched in 2014, serves as exemplary illustration for this section. All its material has been archived on the edX website and is available in OA, after subscribing with an email and password. The course has been presented and analyzed in detail in an article to which one can refer for further information. They note that »the Early Christianity: Letters of Paul through HarvardX was a very simplified portion of an introductory course offered at Harvard for undergraduate, masters, and doctoral students « (Quigley-Nasrallah, 2019, 220). There were 32,036 people in 169 countries enrolled in March 2014. Of these students, 2,748 completed the course, and 1,548 participants received certificates, for an average of $4.8 \%$ of course registrants, while the certification rate of HarvardX in all fields is $6 \%$. Texts, bibliographical references, exercises, short and long interviews, and videos on Paul's letters are available. Short videos discuss topics like »Who is the Author of a Letter, « What Do We Mean by Author, and »How does Paul Characterize Himself in the Prescripts? « An example of a video featuring an interview is one titled, »Professor AnneMarie Luijendijk (Princeton University) Shows Us Ancient Papyrus Letters, « about papyri from the Princeton collection.

In a 2014 YouTube video (https://youtu.be/4Rj3NxOyt7k [Jun 7, 2020]), Nasrallah explains that the purpose of the course is »to actually take [the students] into the Ancient World. Not because the ancient world will answer all of our questions about what the letters of Paul mean. In the experience of trying to go back in time, in the experience of trying to enter into the Mediterranean world, our imaginations are kind of set off «. Moreover, Quigley and Nasrallah share the fact that the project engages » the experiment of feminist pedagogy in a MOOC, « grounded in »ideas from Elisabeth Schüssler Fiorenza's work, [... insisting] upon an ethics of interpretation that is attentive to how biblical texts are often deployed for injustice - to perpetuate racism, sexism, anti-immigrant attitudes, hatred of other religions, and homophobia « (Quigley/Nasrallah, 220; 222). This point of view is cleverly illustrated by a video of Nasrallah entitled $»$ Women in Religious and Political Life in the Ancient World. «In my opinion, this video should be included in all introductory courses in New Testament.

In a comprehensive evaluation of this MOOC on the Pauline letters, one can estimate that the large numbers of certification through this platform is likely not the most important point. The course was offered just once in six years, allowing 1,548 people to acquire a basic certificate. But its impact has been quite impressive, reaching thousands of people, not just those attaining certification. This material, and the videos in particular, should be translated into other languages and integrated into NT introduction courses for discussion and debate, as an effective introduction to the field. 


\section{Editing the Greek New Testament: the "Digital Editio Critica Maior « and the "NT Virtual Manuscript Room"}

The publishing process of the Greek New Testament is undergoing significant evolution in digital culture, and these changes have been noted since some years. In 2008, D. Parker had already predicted a »drastic change « for NTTC with the emergence of digital culture (Parker, 1). The main actors of NTTC are the Institute for the New Testament Textual Research (INTF), the Institute for Textual Scholarship and Electronic Editing (ITSEE, Birmingham), and the International Greek New Testament Project (IGNTP) which is in charge of editing the Editio Critica Major (ECM). The Digital Editio Critica Maior (DECM) presents the state of the ECM »in real time « in the form of an » unedited realtime collation «. It exists presently only for the book of Acts. Previously, the New Testament Transcripts was giving access to all the NT transcripts, but the tool is not maintained anymore. The user signs into the webpages created by the ECM, and can collaborate on ECM. This example points to the changing state of this online edition, always subject to revision. Therefore, allowing researchers access to past versions would be a useful modification. If the $29^{\text {th }}$ paper edition of the Nestle-Aland Greek New Testament is in process, as well as the continuous paper edition of each ECM NT book, the DECM is positioned as an evolving consultable tool. The examination of scholars' uses of the DECM in comparison to print editions will indicate which form they consult more often in their work. An overview of this question can be found in the work of Houghton (Houghton).

Developments such as the NT Virtual Manuscript Room (NTVMR) are introducing digital culture and new ways of conceiving NT publications, like the manuscripts available online at the Center for the Study of New Testament Manuscripts (http://www.csntm.org/), or on PAVONe - the platform of Arabic versions of the New Testament (http://pavone.uob-dh.org/) or the project »Paratexts of the Bible « that »catalogues all available material in an e Clavis [and ...] develops a set of categories according to which each paratext of the New Testament is edited according to internal criteria (http://paratexbib.eu/ [all Jun $7,2020])$. Without a doubt, the NTVMR is one of the most important virtual research environments for the study of the NT and is largely interactive: scholars, when enrolled, can collaborate on the manuscript transcription tool. It has been presented in a recent article in detail by G. Allen, who summarizes:

"Not only is the NTVMR the platform where the digital workflows of the ECM editorial projects are managed, comprising image aggregation, transcription, collation, normalization of readings, and now also publication, but it is a place where scholars beyond the immediate ECM editorial teams can create tools that interpret, supplement, or further contextualize the textual research published there. The NTVMR replaces the need to travel to the INTF in Münster: every primary source and the main tools that the INTF possess are becoming available in a digital workspace, combined with hyperlinked access to multiple related resources« (Allen, 15). 
To look at the NT first as a sea of manuscripts leads one to reconsider the »textuality « of the NT. Digital editions for various Humanities texts or works have a »decanonizing effect, « as argued by S. Mombert (Mombert). But as long as readers ask to read the New Testament, its identity as a coherent and complete text will probably endure, even in a very new format, like the movie published at the end of 2019 by KoineGreek.com that uses the Greek Gospel according to Mark as script.

\section{Nichts Neues für die Alte Kirchengeschichte? Das Internet als Ernstfall bistorischer Heuristik}

Katharina Heyden

Bibliothek der Kirchenväter online, Université de Fribourg, online: https://bkv.unifr.ch/ (07.06.2020). - Corpus Thomisticum, Universidad de Navarra, online: https://www.corpusthomisticum.org/ (07.06.2020). - e-codicology, Technische Universität Darmstadt, online: http://www. ecodicology.org/ (07.06.2020). - Franz Fischer (Hg.), Magistri Guillielmi Autissiodorensis Summa de officiis ecclesiasticis. Kritisch-digitale Erstausgabe, Cologne Center for eHumanities $\mathrm{CceH}$, online: http://guillelmus.uni-koeln.de/tcrit/tcrit_prologus (07.06.2020). -James J. O’Donnell (Hg.), The »Confessions « of Augustine. Text and Commentary, Oxford University Press Oxford 1992. An Electronic Edition, online: http://www.stoa.org/hippo/index.html (07.06.2020). - Pinakes. Textes et manuscrits grecs, Institut de recherche et d'histoire de textes, online: https://pinakes.irht.curs. fr/ (05.07.2020). - prometheus. Das verteilte digitale Bildarchiv für Forschung und Lehre, https:// www.prometheus-bildarchiv.de/ (07.06.2020). - Wikipedia. Die Freie Enzyklopädie, Art. Confessiones, online: https://de.wikipedia.org/w/index.php?title=Confessiones\&oldid=199339509 (Permalink, letzte eingesehene Version vom 23.03.2020). - Zentrum für Augustinus-Forschung, Julius-Maximilians-Universität Würzburg, online: https://www.augustinus.de/ (07.06.2020).

\section{Einführung: Nichts Neues?}

Die Kirchengeschichte des Mittelalters kann sich rühmen, mit dem Index Thomisticus vor über 70 Jahren den Anstoß für die Entwicklung von Digital Humanities gegeben zu haben. Heute erweist sich das Internet als Ernstfall der historischen Heuristik, also der Kunst, mit begrenztem Wissen in einem unübersichtlichen Feld von Informationen diejenigen Quellen zu finden, die zur Beantwortung einer Forschungsfrage geeignet sind. Das Suchen und Finden geeigneter Quellen ist kein Problem, mit dem erst das Internetzeitalter die historische Forschung konfrontieren würde. Die Heuristik, von J.G. Droysen in seinem »Grundriss der Historik«als »Bergmannskunst« des Historikers bezeichnet ( $\mathbb{2 0}$ : http://www. deutschestextarchiv.de/book/view/droysen_historik_1868?p=22 [07.06.2020]), ist schon immer eine heikle Kunst gewesen. Wie kann man sinnvoll auswählen, 